\title{
Implications of Dalalah Amr in Terms the Law of Serving in Covid19 Pandemic Situation
}

\author{
Asmuni $^{1}$, Hasan Matsum ${ }^{2}$, Hadi Munawwar ${ }^{3}$ \\ ${ }_{1,2,3}$ Islamic Law Study Program, Universitas Islam Negeri Sumatera Utara, Indonesia
}

\begin{abstract}
It is an agreement of the ummah, that what Allah revealed in the Al-Qur'an and also what was conveyed by the Messenger of Allah in the Hadith are the basic sources of Islamic law. The two sources, of which there is an order (Amr), this Amr has various meanings such as obligatory, mustahab and others. In this study, the researcher attempted to describe the views of the scholars of jurisprudence in understanding the meaning of amar and its implications for one of the Islamic laws, and here the researcher took one case, namely the practice of worship during the Covid-19 Pandemic. Although most of the Ulama proposing fiqh are of the view that amr basically has a mandatory meaning unless there is a qarinah, in practice there are differences between them. In this study, the researcher used an analytic descriptive method in which after the researcher described the views of the Ulama with regard to the meaning of amr, the designation of the meaning of amar and the legal implications of practicing worship during the Covid-19 Pandemic, considering that at this time there were differences in worship practices that had never happened before Furthermore, the researcher provides some analysis of what the researchers understand based on the views of scholars and experts in this matter.
\end{abstract}

Keywords

dalalah amr, worship; prayer, covid 19



\section{Introduction}

COVID-19 is a global health problem including Indonesia. This was initiated from the information of the World Health Organization (WHO) on 31 December 2019 there was a case of a cluster of pneumonia with a new etiology in Wuhan City, Hubei Province, China and later expanded beyond China. On 30 January 2020, COVID-19 was set to become the public health Emergency of International Concern (PHEIC). On 11 March 2020, COVID-19 was designated as a pandemic. Indonesia first reported 2 positive cases on March 2, 2020 and a positive case continued to increase (Kementrian Kesehatan RI, 2020a). Until April 25, 2020, Indonesia already reported 8. 211 Positive cases, 689 cases died, 1.002 cases recovered from 50,563 people examined with the results of the examination is 42,352 negative (Kementrian Kesehatan RI, 2020b). (Susilawati, 2020)

The current COVID-19 lockdown situation has had an impact on people's connectedness by limiting their allowed behaviours, resulting in a negative impact on people's mental health and well-being on the whole. The enhancement of human interaction and networking to sustain people's mental health has been on the emergent agenda during the current COVID-19 situation. (Oe, 2020) Not only in the form of measurable and clearly visible economic impacts. Another impact resulting from Covid-19 is actually also felt by many individuals-communities such as increased anxiety, stress and panic that is included in this context is Panic Buying. Accurate data about the situation have not been described in 
research reports, but if collected in a variety of psychological opinions in the news media. (Saleh, 2020)

The Islamic Shari'at that came to humans is based on Al-Qu'an which was later explained by the Prophet Muhammad, both with his words and deeds, where his words and deeds are what is said to be Sunnah. At the time when the Qur'an came down as well as the Hadith, the Muslim community (friends) did not need regulations in taking a law (istimbat), as they did not need qaidahs to know their language, namely Arabic.

After the Prophet Muhammad died and Islam experienced a development where the Arabs had mingled with other nations, Arabic regulations were made, in order to protect Arabic as the language of the Qur'an from the influence of foreign languages. Among the rules that are attempted by the scholars are the Usul Fiqih which discusses the sources of syara 'in terms of its designation to the law of the actions of mukallaf, where the syara law' can basically be divided into two, namely Taklifi law and wadh'i law.

One of the decrees of Allah related to the actions of the mukallaf in the form of iqtidha 'is a demand in the form of an order. Demands of orders in terms of ushul fiqih are called AlAmr. For that, in order to understand the occurrence of a syara 'law with certainty and truth, it is necessary to use the rules of ushul fiqih, one of the taklifi laws that use the rules of ushul fiqhi is Amr's demands.

To better understand the problem of Al-Amr (orders or orders), the researcher will discuss or study further problems related to Amar.

\section{Review of Literature}

\subsection{Definition of Amar}

Amar comes from the Arabic word "الأمر" which has several meanings including



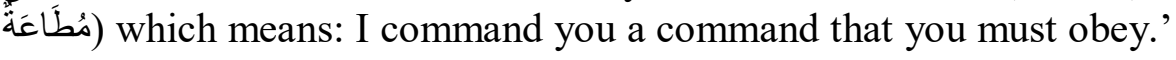

Ibnu Al Jauzi said that Amar had two views of meaning:

1. Amar, whose plural form is "awamir" (أََامِر ) means a demand to do something by means of words from the top down.

2. Amar which the plural form is "Age" (أُمُوْر) means form, state and story.

The Ushul Fiqh scholars have different definitions in the meaning of amr, but in general there is not much difference. Here are some definitions of the proposed scholars:

- The definition mentioned by Imam Al Baqillani and followed by Imam Al Haramain and Al Ghazali:

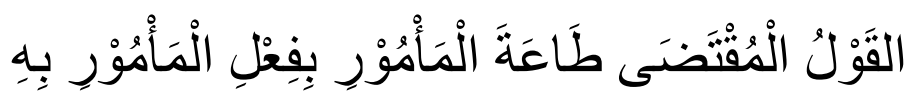

Meaning: The words that contain obedience to the command to do what is commanded.

- The definition corroborated by Imam Al Razi, followed by Al Amidi:



Meaning: Demands to do something from the above.

- The famous definition according to the Ulama Ushul Hanbali School, mentioned by Abu Al Khattab Al Kalwazani, followed by Imam Ibn Qudamah: 


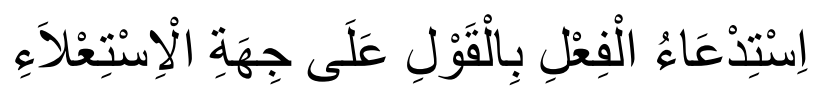

Meaning: "The demand for action from the above direction.

\subsection{Form Amar}

The form of amr here is what the Prophet Muhammad SAW said that he had spoken in various fields, such as Law, Akhlaq, Aqidah, Education and so on (hadith Qauly).

Amr or commands in Arabic have several prayers and uslub, namely:

1. Shighat amr which is commonly known, namely, lafaz that uses if'al scales and such. For example, the word of Allah swt:

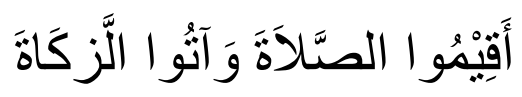

2. Shighat mudhori 'which is accompanied by lam which is meant for commandment. For

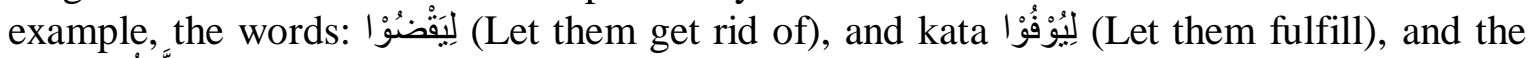

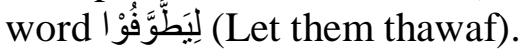

Apart from the two mentioned above, there are also other forms of amr or commands, namely:

3. Isim Fi'il Amar, namely Isim which means fiil amar, occupies the place of fi'il and shows the meaning of amar. An example is the Word of Allah swt:

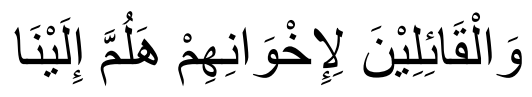

4. Lafaz Amar in Masdar form. Because sometimes orders can come in masdar form, such as the Word of Allah: الرَََّابِ فَضَرْبَ ..., this sentence is in the form of masdar which mansub deeds fiil amar. And the Hadith of the Prophet Muhammad which says: يَاسٍِِ آلَ يَاصَبْبرًا

\subsection{Dalalah Amar}

Amar that is in the Shari'a, be it al Qur'an or al Hadith, has three meanings:

1. Has a mandatory meaning, if there is a qarinah that the commandment contains mandatory meaning. As the word of Allah الصَّلاة وَأَفِيْيُو ال (And Establish Salat) has an absolutely obligatory meaning because there is a Qarinah from the Holy Book, Al Sunnah and also Ijma 'of the Muslims for the obligation of five daily prayers.

2. Has an optional meaning, as stated by the Messenger of Allah in Sahih al Bukhori (1183):

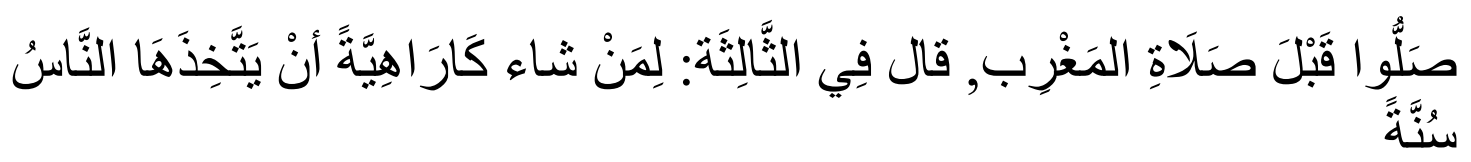

Meaning: Pray before maghrib, on the third time he said: for those who want, worry about making it a sunnah that must be followed. The saying "For those who want" is evidence or qarinah which shows that praying before sunset is not obligatory.

3. Has a mandatory meaning, if the amar does not have any qarinah, the scholars give the

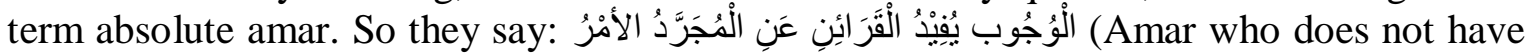
Qarina indicates obligatory). And this is what most scholars in the four schools hold. 


\section{Discussion}

\subsection{Worship Practices during the Pandemic Covid-19}

At the level of practice, there is a difference between what has been explained and even agreed upon by the scholars and what applies among the Islamic community, especially during the Covid 19 pandemic. Some mosques during the pandemic implemented worship activities by maintaining health protocols such as partial absence. pilgrims who may be in a state of illness, even though they have a minor illness such as flu and others. There is also stretching the shaf between congregation by about one meter in the context of implementing physical distancing, and also wearing a mask during prayer services, which all have an impact on reducing the capacity for congregational prayers at the mosque.

In matters of worship, especially prayer, there is an order from the Prophet Muhammad who ordered prayer as he prayed. Rasulullah SAW said:

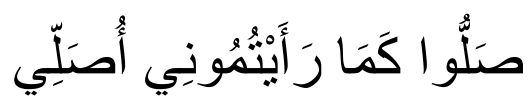

Meaning: "Pray for you as you see me praying"

The above command is in the form of amr, which was conveyed by the Prophet. Amr has a mandatory meaning, so praying as the Messenger of Allah (saw) is an obligation. Here the scholars agreed to state the obligation to pray as did the Prophet. This hadith also explains what is written in the Al-Quran which reads:



Meaning: "And uphold prayer and pay zakat"

The Prophet's hadith, which functioned as a bayan (explanation) for the Qur'an, often had a detailed and operational eye. This was mainly so that the messages contained therein could be digested and practiced by the people at that time. The generality of the messages contained in the Koran (mujmal verses), will be difficult to understand and put into practice when they are not elaborated and detailed by the hadiths of the Prophet, because of their detailed and operational nature, so that they can be understood and practiced. by the people who lived at the time of the Prophet SAW, the Hadith is very contextual, meaning that it is appropriate and follows the existing context at that time, both social, cultural and scientific that developed at that time.

In this case, researchers pay attention to several worship practices carried out by the Islamic ummah which are different from what was said by Rasulullah SAW and agreed upon by the jurisprudence scholars and also Usul Fiqh scholars who have laid the foundation of the science of fiqh which is the guideline and reference in laying down one Islamic law. Some of these cases the researchers will describe in this research, namely:

\section{a. Stretch the Shaf When Performing Congregational Prayers}

The scholars of the School agree on the necessity to straighten and close the rows in prayer, but they differ on whether it is obligatory or Sunnah. The opinion that says that it is obligatory to doistidlal with a hadith narrated by Malik Bin Anas in which the Prophet Muhammad said: 


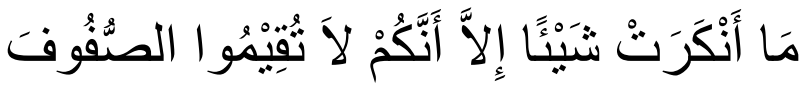

Meaning: "I do not deny something but that you do not uphold the shaf"

Also the Prophet's other commands:

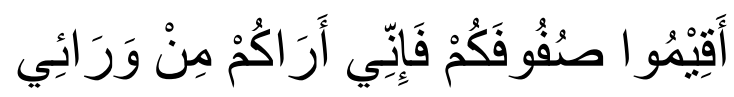

Meaning: "Uphold your Shaf, because I see you from behind me".

Even so, Jumhur Ulama is of the view that straightening and tightening the rows is Sunnah Muakkadah, it is not sinful for those who leave it, but he loses goodness and great reward. In the current context of Covid19, of course the application of amr here has changed. What originally meant obligatory or Sunnah muakkadah, as the opinion of jumhur, cannot be applied. Because the condition as a syar'iyyah intention. This is as stated in the MUI fatwa No.31, Point.3 of 2020, states: (c) To prevent the transmission of the COVID-19 epidemic, the application of physical distancing during congregational prayers by stretching the legal safeguards is permissible, prayers are valid and do not lose the virtue of congregation because this condition is a syar'iyyah necessity. Even in line with the MUI fatwa above, the fatwa section of the Kingdom of Saudi Arabia with its fatwa No.28068, dated 17/09/1441 says that it is okay to stretch out the shaf and the prayers are valid.

\section{b. Implementation of Fridlay Prayers}

In the implementation of Friday prayers, there are several requirements that become a person who is obliged to carry it out, namely:

a. Men, it is not obligatory to pray Friday prayers for women.

b. Freedom, as for a servant is not obliged

c. Mukim, or not in a traveler's state.

d. Congratulations from aging.

Wahbah Al Zuhaili describes his age here as health, security, freedom, vision, being able to walk, not being imprisoned, not in a state of heavy rain, flood or snow or others.

The most powerful argument in stating the obligation to pray Friday is in the Al-Qur'a surah Al Jumu'ah verse 9:

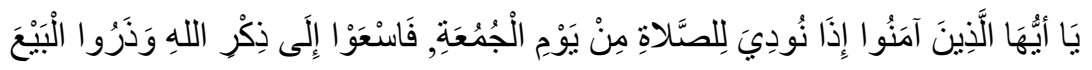

Meaning: "O people, who believe, if you have been called out to pray on Friday, then immediately remember Allah and leave the buying and selling"

At the time of the Covid19 pandemic, the command amr in the above verse was still understood to be in accordance with the text of the verse, but the context changed when there was age. And covid19 according to what health experts say is an age that can change the obligations of Friday prayers. However, it needs to be understood that the age has a level, where if it is lost, then the obligation to perform Friday prayers still applies.

In the MUI fatwa No.31 of 2020, states: Basically Friday prayers can only be held once in one mosque in one area. To prevent the transmission of the COVID-19 outbreak, Friday prayers may apply physical distancing by means of safeguarding. If the Friday prayer congregation cannot be accommodated due to the implementation of physical distancing, then 
it is permissible to hold multiple Friday prayers (ta'addud al-jumu'ah), by holding Friday prayers in other places such as mushalla, hall, meeting hall, sports hall, and stadium. In the event that mosques and other places still do not accommodate the congregation for Friday prayers and / or there is no other place for Friday prayers, the MUI Fatwa Commission Session has a different opinion on the congregation who has not been able to perform Friday prayers as follows: (Opinion first), the congregation may hold Friday prayers at mosques or other places that have performed Friday prayers with the shift model, and the implementation of Friday prayers with the legal shift model is valid. (Second opinion), the congregation performs the Zuhur prayer, either individually or in congregation, and the implementation of Friday prayers using the legal shift model is invalid.

\section{c. Using a Mask When Praying}

In general, the scholars of the School say that praying by covering the nose and mouth is makruh, in fiqh terms it is called talassum (covering the face or mask). According to the Shafii School of talassum, it is to cover the mouth, according to the Hanafiah and Hanabiah Schools it means to cover the mouth and nose. In the Maliki school everything that covers the end or lower lip. So praying someone, whether male or female, wearing a face covering is makruh.

In the context of the COVID-19 pandemic, there are several fatwas related to this problem such as the fatwa issued by the Fatwa and Research Section at Al Azhar Egypt which states that the agreement between scholars and jurists is the ability to cover the faces of both men and women in prayer with a note that there are worries spreading outbreaks of disease, or causes the transmission of viruses, or other causes.

In the MUI fatwa No.31 of 2020, it states:

a. It is permissible to use a mask that covers the nose during prayer and the prayer is valid because the nose is not a part of the body that must be attached to the place of prostration during prayer.

b. Shutting your mouth during prayer is makruh, unless there is a syar'iyyah intention. Therefore, pray using a mask because there is a desire to prevent it

\section{Conclusion}

From what has been described above, the following conclusions can be seen:

1. Most of the Ulama agree in terms of the obligation to follow everything that was done by the Prophet Muhammad in the rituals of worship, especially prayer. Because one of the most obvious commands by the Apostle that said "Pray you as you see me pray". What was ordered by the Prophet Muhammad is an explanation contained in the Qur'an, which says: "Uphold prayer and pay Zakat". The commands that are in the Al-Qur'an and this Hadith are amr, and amar shows the meaning of obligatory unless there is a qarinah that deviates from the obligatory meaning.

2. Although the commands of the Messenger of Allah exist and generally indicate mandatory meanings unless there is a qarinah, there are differences in practice. This depends on the understanding of the scholars in interpreting the amr and also the strength of the qarinah which can divert the meaning of amr from obligatory to sunnah. So it is found that in one amr (command) there are those who understand obligatory but there are those who understand the Sunnah, depending on them saying there is qarinah while others say there is no qarinah.

3. In the context of the current Covid19 pandemic, it is imperative to protect yourself and those around you from this deadly virus. Among the forms of self-protection is not going 
to the crowd. So in the case of worship during a pandemic, it certainly has special attention. So that the fatwa of the ulama and also the world fatwa institutions emerged. The fatwa that is easiest to access and is from the Indonesian fatwa institution, namely the fatwa of the Indonesian Ulema Council (MUI) which has issued fatwa No.31 of 2020 regarding the Covid19 pandemic. This MUI fatwa is in line with the fatwa that was also conveyed by world fatwa institutions such as Egypt and Saudi Arabia, where the essence of the fatwa is that it is permissible not to attend congregational prayers and even Friday prayers if there is a fear of spreading the Covid19 virus among congregations, and even though it is implemented worship in congregation, so keep the protokes healthy, so that you can see some mosques using the physichal distencing system by giving the congregation a distance of about 1 meter and wearing masks, even though there is an order (amr) from the Prophet Muhammad that requires closing the rows and also prohibition to cover one's face in prayer. However, due to the necessity of circumstances, and the fear of the spread of the plague, as the fiqh rule says "Emergency can allow the prohibited".

\section{References}

Abu Al Husain, Ahmad Bin Faris Bin Zakaria, Mu'jam maqayis al Lughoh. (1979) Libanon: Dar Al Fikr.

Al Ghazali, Abu Hamid hammad Bin Muhammad, Al Mustashfa Min Ilmi al Usul, Madina, Univ.Islam Madinah, t.t.p.

Al Amidi, Imam Ali Bin Muhammad, Al Ihkam fi Usul al Ahkam. (2003). KSA: Dar al Sumai'i

Al Kalwazani, Abu Al Khattab, Al Tamhid fi Usul Al Fiqh, KSA: Dar Al Madani, $1406 \mathrm{H} / 1985 \mathrm{M}$

ARFA, Faisar Anana; Nasution, M.; Syam, Syafruddin. (2015). Metode Studi Islam: Jalan Tengah Memahami Islam.

QORIB, Ahmad.( 1997) Ushul Figh 2. Jakarta: Nimas Multima, cet,2.

Al Rifai. (2006-2007).Rafi' Bin Taha, al Amr inda al usuliyyin, Damaskus: Dar al Mahabbah.

Al Hakim An Naisaburi, Abu Abdullah, Al Mustadrak ala as Shohihain. (1986). Libanon: Beirut, tahun.

Al Hambali, Muhammad Bin Ahmad Bin Abdul Aziz, Bin Ali al Futuhi, Syarh Al Kaukab Al Munir. (1993). KSA: Maktabah al Ubaikan.

Oe, H.et al. (2020). The enhancement of human interaction and networking to sustain people's mental health has been on the emergent agenda during the current COVID-19 situation. Budapest International Research and Critics Institute-Journal (BIRCIJournal). P.1369-1377

Saleh, A.et al. (2020). Challenges and Opportunities for Community Empowerment Practices in Indonesia during the Covid-19 Pandemic through Strengthening the Role of Higher Education. Budapest International Research and Critics Institute-Journal (BIRCIJournal). P. 1105-1113

Susilawati,et al.(2020). Impact of COVID-19's Pandemic on the Economy of Indonesia. Budapest International Research and Critics Institute-Journal (BIRCI-Journal).P. 11471156

Yuslem, Nawir. (2010). Kontekstualisasi Pemahaman Hadis. dalam MIQOT: Jurnal Ilmuilmu Keislaman, 34.1., hal.19-20

Twitter resmi dari lembaga Fatwa Kerajaan Saudi Arabia: https://twitter.com/aliftasa/status/1265757438868946945?s=19

https://nabd.com/s/70246150-82329d/ 